\title{
Pertamini Business Feasibility in Perspective of Law No. 22 of 2001 on Oil and Gas
}

\author{
Ni Made Puspasutari Ujianti ${ }^{1}$, Anak Agung Sagung Laksmi Dewi ${ }^{2}$, Desak Gde Dwi Arini ${ }^{3}$ \\ Faculty of Law, Universitas Warmadewa, Denpasar ${ }^{1,2,3}$ \\ \{info@warmadewa.ac.id $\left.{ }^{1}\right\}$
}

\begin{abstract}
The law on oil and gas already regulates how to utilize this resources to avoid the exploitation and distribution to gas stations in each region. However, oil-fuel retailers with the Pertamini brand are commonly found in the community today, which when viewed from the Oil and Gas Law, are certainly not in accordance with what has been regulated in the legislation. As a result, It is very important to carry out this research with the aim of ascertaining pertamini business feasibility review from the Indonesian legislation. It is also to make the general public understand the importance of public safety in Pertamini business. Therefore this research was designed using the normative method and the data is in form of primary and secondary legal sources. Buying and selling of fuel oil can only be carried out by Cooperatives, Private Business Entities, Regional and State owned Enterprises, after they have obtained a business license from the government. This is stated in article 9 paragraph 1 of law No. 22 of 2001 on Oil and Gas. The government does provide an opportunity for small businesses to legally sell fuel oil through the regulation of Oil and gas Downstream Regulatory Agency No. 6 of 2015 with the aim of equitable distribution of fuel oil. In addition, the Factors that influence the increasing number of fuel sellers with the Pertamini concept in Denpasar City are the high number of motor vehicles, especially two-wheeled motorcycles, high public interest, ease of selling and the high profit in this business.
\end{abstract}

Keywords: Business feasibility; Pertamini

\section{Introduction}

Oil Fuel is a natural resource controlled by the state as well as a vital commodity that controls the lives of many people and at the same time has an important role in the national economy, so that its management must be maximized. Therefore, Law No. 22 of 2001 on Oil and Natural Gas was formed. The Law on Oil and Gas regulates how to use oil and natural gas resources from exploitation to distribution to gas stations in each region. Broadly speaking, the distribution channel of fuel oil starts from existing storage facilities and is then transported to storage installations and then distributed to depots and partly directly to industries and General Fuel Filling Stations (SPBU) using tank trucks.

The law on oil and natural gas regulates the provisions regarding business licenses, upstream and downstream business activities. The government issues a business license, after 
that, the business entity has a recommendation from the local government. Business licenses granted by the government are in accordance with their respective authorities to carry out processing, transportation, storage and / or trading business activities, after meeting the requirements and are required in matters relating to regional interests. The business license in the form of SIUP (Trading Business License) is a license issued by the minister or official appointed to entrepreneurs to carry out business activities in the trade and services sector. Trading business permits (SIUP) are given to entrepreneurs, both individuals, firms, CVs, PTs, cooperatives, and BUMN (Harahap, 2018).

The emergence of the phenomenon of selling fuel oil with the first name is due to economic development and the lack of supervision carried out by the government in the downstream business of fuel oil. The concept of the first sale of fuel is that the seller stores the gasoline in a drum equipped with a pump. The pump is operated manually by turning it several times, then the gasoline will rise to fill the small tank above the drum. Then from this small tank the gasoline is flowed to the motor vehicle tank via a hose. It is also necessary to know that the fuel oil seller who uses this first name makes the color of the building and the $\operatorname{logo}$ as if it resembles the official Pertamina gas station. The first time indirectly had a negative impact on the state and society. The fuel subsidy that has been given to the community should be used maximally for the welfare of the community. However, with the phenomenon of the first petroleum retailer, the state has been disadvantaged because it has issued an APBN budget to subsidize fuel, which has been misused by petroleum retailers who use the first name who are looking for profit for themselves.

Several studies regarding the current problem have been previously reviewed, such as Utomo (2017) saying that at first it can be equated with illegal retail fuel sellers who violate article 53 and article 55 of the Oil and Gas Law which the government really needs to pay attention to. More than that, business actors are obliged to provide compensation to consumers who have suffered losses. Then, Gultom (2018); Simanjuntak (2017) states that the existence of the Pertamina retail petrol dealer in remote areas makes it easy for the community because the official gas stations are far from where they live. However, people complain because of the difference in price compared to official gas stations. These losses can be resolved by reporting to the police or filing a lawsuit to the district court. The legality of retail sales of fuel oil by the first company has not yet been granted by the government. The distribution requirements include membership, location of establishment, storage capacity, owning or controlling fuel transportation equipment, having distribution equipment that meets technical and work safety requirements, having consumer data (Pangesti, 2018). The crime of selling fuel using the name Pertamini has not been able to run properly because Law Number 22 of 2001 concerning Oil and Natural Gas has not regulated the distribution of fuel to fuel retailers using the Pertamini brand (Hendri, 2016). Based on the above background, the puIDRose of this new research is to determine the feasibility of the first business in terms of the laws and regulations in Indonesia and to provide an understanding to the public about the importance of public safety in the first attempt.

\section{Research Method}

This study was designed using the normative method by examining existing legal literature. Sources of legal materials used are sourced from literature research in the form of primary legal material sources based on Law of the Republic of Indonesia Number 22 of 2001 
concerning Oil and Gas and secondary sources of legal materials obtained from books, theses, journals and documents that can support of this research.

\section{Results and Discussion}

\subsection{The Feasibility of the First Business in Terms of Positive Law in Indonesia}

A Feasibility Study can be carried out to assess the feasibility of investing in both a project and an ongoing business (Harahap, 2018). According to Soemitra (2015) that a business feasibility study is an activity that studies in depth about a business activity that will be carried out, in order to determine whether or not a business or business is feasible (Subagyo, 2010; Umar, 2015). In line with Ibrahim J (2013) in Harahap (2018:4) defines a business feasibility study as a consideration in making a decision, whether to accept or reject an idea/project that is planned.

Along with the development of the nation, law in Indonesia must also evolve in order to adapt to developments that occur. Indonesia is known as a country with abundant natural wealth. As a rule of law, Indonesia has a 1945 Constitution to regulate all of these matters. This can be seen in article 33 paragraph (2) of the 1945 Constitution which states that the land and water and the wealth contained therein are controlled by the state and used for the greatest prosperity of the people. One of the natural resources that has a huge influence on the interests of the Indonesian nation is oil and natural gas. Oil and natural gas are included in the strategic mineral category for the State.

Based on the classification of minerals that classify Petroleum into group A, namely, minerals that are strategic for the State, then further regulated in Article 4 of Law No.22 of 2001 on Oil and Natural Gas which states that oil and Gas as Strategic non-renewable natural resources contained in Indonesia's mining jurisdiction are national assets controlled by the State. So the implementation of oil and gas activities in Indonesia is fully carried out by the State. One of the objectives of carrying out oil and gas business activities, as stipulated in Article 3 letter b of Law Number 22 of 2001 concerning Oil and Natural Gas is to ensure the effectiveness of the implementation and control of processing, transportation, storage and trading businesses in an accountable manner., which is organized through fair, healthy and transparent business competition mechanisms.

The existence of a retail petrol seller in the community has many benefits. The distance from where to buy fuel oil at gas stations makes retail petroleum fuel sellers an alternative for the community. As time goes by, the type of sale of fuel oil by using bottles to put fuel oil is now starting to be abandoned. People are now starting to switch to imitating the sale of fuel oil at gas stations. First, with the sale of fuel oil using a machine or pump, which is now in great demand by retail gasoline sellers. By using a pump to deliver fuel oil to the buyers' tanks, at first it is also equipped with a measurement in the form of a transparent tube.

The first business activity in circulation has become a phenomenon of rapid economic development among the middle class. However, the position of the first business activity in the Oil Fuel trading business activity is still questionable. According to Law no. 22 of 2001 concerning Oil and Gas has regulated the provisions for oil and gas business activities from upstream to downstream. Oil and Gas Sales activities are regulated in article 1 paragraph (10) of Law no. 20 of 2001 concerning Oil and Gas, which states that downstream Business Activities are business activities that are core or based on processing, transportation, storage, and/or trading business activities. Whereas in Article 1 paragraph (14) Law no. 20 of 2001 
concerning Oil and Gas states that commerce is the activity of buying, selling, exporting, importing Crude Oil and/or its processed products, including Natural Gas Trading through pipelines.

Oil Fuel sales activities are included in the downstream business activities categorized as commercial business activities as regulated in Article 1 paragraph (10) and Article 1 paragraph (14) of Law No. 20 of 2001 concerning Oil and Gas. In the provisions of upstream and downstream business activities based on the provisions of Article 9 paragraph (1) of Law no. 20 of 2001 concerning Oil and Gas, upstream and downstream business activities can be carried out by:

a. State-owned enterprises

b. Regional owned enterprises

c. Cooperatives, small businesses

d. Private business entity

Small businesses as referred to in Article 9 paragraph 1 letter c are small businesses in the form of business entities in accordance with the intent of Article 23 paragraph (1) where it says that downstream business activities as regulated in Article 5 paragraph (2), can be carried out by business entities that have obtained a business license from the government. In the division of business entities, there are various forms of views that apply in Indonesia. Business entities can be divided into 2 (two), namely business entities with legal status and business entities with non-legal status. A business entity with a legal status has limited responsibility for the personal assets of the founders of the business entity or the management of the business entity, so that the assets that are charged for the collection of debts and receivables of the business entity are only limited to assets owned by the business entity and cannot be charged to the personal assets of business entity founders or business entity managers (Dijan, 2012).

A non-legal entity business entity has unlimited responsibility for the personal assets of the founders of the business entity and the management of the business entity, so that personal assets as assets outside the business entity are subject to all forms of receivables that are actually addressed to the business entity. Business entities that are not in the form of a legal entity include trading companies, civil partnerships, firm partnerships, and limited partnership (Dijan, 2012). According to the criminal provisions of Law no. 22 of 2001 concerning Oil and Gas. Basically, the petroleum trading business activity, if it does not have a business license in accordance with the terms and conditions stipulated by the laws and regulations, can be punished.

The business activity of buying and selling fuel oil with the first name is illegal by the community. Because Pertamina's business activities are not in accordance with those categorized as petroleum trading business activities as regulated in article 1 paragraph (10) and article 1 paragraph (14) of Law no. 20 of 2001 concerning Oil and Gas. To carry out the activity of selling fuel oil, it must pay attention to the quality standard of the fuel, occupational safety and health as well as environmental management, good engineering principles, and the use of measuring equipment and systems in business activities. As described in Article 6 of Government Regulation Number 30 of 2009 concerning Amendments to Government Regulation Number 36 of 2004 concerning Oil and Gas Downstream Business Activities The

Government has provided facilities to the public to legally sell fuel oil as a sub-distributor by following the appropriate conditions regulated with the provisions of the BPH Migas Regulation No.6 of 2015 concerning "Distribution of Certain Types of Fuel and Assignments of Special Fuels to Areas Unable to Distribute". If the community still chooses to sell Oil Fuel by illegal means, the criminal provisions of Law no. 22 of 2001 concerning oil and 
natural gas Article 53 and Article 56. It is supposed that the first business activities must be curbed from circulation because they do not comply with regulations and do not have legal permits to carry out their business activities in the sale and purchase of Oil Fuel.

\subsection{Factors that cause the rise of first-line businesses in Denpasar} factors:

The rise of Pertamini in the North Denpasar District area, in general, is caused by several

\section{a) The high number of vehicles in the city of Denpasar}

Based on statistical data released by the Bali Provincial Statistics Agency, the number of motorized vehicles in the Denpasar City area is 1,292,618 vehicles (data for 2017), Denpasar City is in the top rank in terms of the number of motorized vehicles compared to districts in Bali Province that burn retail oil such as Pertamini.

\section{b) The high public interest in buying fuel oil in Pertamini}

The high mobility of the people of Denpasar City, the distance between the house and their place of work and school, traffic jams are the reasons that Denpasar residents are always pressed for time and are always in a hurry. The classic reason for being lazy to queue for too long at Pertamina is one of the reasons consumers buy fuel oil at Pertamini.

\section{c) Ease of opening a first business}

On the one hand, Pertamini in Denpasar City benefits residents who do not want to wait in line at Pertamina for a long time, but on the other hand, security is certainly very risky and dangerous for residents around the Pertamina fuel oil seller.

\section{d) Big profits for traders of first fuel oil the first}

Tube seller openly promotes on social media, with the lowest price of IDR. 7,800,000, (seven million eight hundred thousand rupiah) with the specification of the tube material made of stainless and iron plate with a fuel capacity of 210 liters. In addition, the price of fuel oil sold through Pertamini is also higher than the price sold at Pertamina. The average price increase is around IDR. 500, - up to IDR. 1.000, - per liter, with the assumption that daily sales can reach at least 50-200 liters. Thus, Pertamini can get a profit of around IDR. 750,000, - up to IDR. 3,000,000, -

\section{Conclusion}

The first business arrangements that occur in society are included in downstream business activities as regulated in Article 1 paragraph (10) of Law no. 22 years In addition, if seen from Article 9 paragraph (1) of Law no. 22 of 2001 concerning Oil and Gas, that the sale and purchase of fuel oil can only be carried out by BUMN, BUMD, cooperatives, private ente IDR rises, which afterwards get a business license from the government. The government does provide opportunities for small entrepreneurs to sell fuel oil legally through BPH Migas 
Regulation No. 6 of 2015 with the aim of equitable distribution of fuel oil. The factors that influence the increasing number of fuel oil sellers with the first concept in Denpasar City are the high number of motorized vehicles, especially two-wheeled motorbikes, high public interest, the ease of selling first-concept fuel oil and the high profit from doing business with the first concept of fuel oil.

\section{References}

[1] Dijan, W. (2012). Hukum Dagang. Yojgakarta: CV Andi Offset.

[2] Gultom, H. (2018). Legalitas Kegiatan Usaha Pengecer Minyak Pertamini Dikaitkan Dengan Undang-undang Nomor 8 Tahun 1999 Tentang Perlindungan Konsumen. Universitas Kristen Maranatha.

[3] Harahap, S. (2018). Studi Kelayakan Bisnis: Pendekatan Integratif. Medan: FEBI UINSU Press.

[4] Hendri, M. (2016). Tinjauan Yuridis Penjualan BBM dengan Nama Pertamini Dihubungkan dengan Undang-Undang Nomor 22 Tahun 2001 tentang Minyak dan Gas Bumi.

[5] Pangesti, I. (2018). Analisis Yuridis Legalitas Penjualan Bahan Bakar Minyak Eceran oleh Pertamini.

[6] Simanjuntak, F. (2017). Kedudukan Pedagang Bensin Eceran Pertamini dalam Transaksi Penjualan Bensin ditinjau dari Undang-Undang nomor 22 tahun 2001 Tentang Minyak dan Gas Bumi. Universitas Sumatera Utara.

[7] Soemitra, A. (2015). Kewirausahaan Berbasis Syariah. Medan: Penerbit CV. Manhaj Medan dengan Fakultas Syariah dan Hukum UIN Sumatera Utara.

[8] Subagyo, A. (2010). Marketing In Business. Jakarta: Mitra Wacana Media.

[9] Umar, H. (2015). Studi Kelayakan Bisnis (2nd ed.). Jakarta: Gramedia.

[10] Utomo, D. (2017). Perlindungan Hukum Bagi Konsumen Pertamini yang tidak Memiliki Peralatan Penyaluran yang Memenuhi Persyaratan Teknis dan Keselamatan Kerja. Universitas Jember. 